\title{
DISAMBIGUATING PRAXIS FROM PRACTICE IN NATURAL RESOURCE MANAGEMENT: A PRACTICAL SPACE FOR ENHANCING EXPERIENTIAL LEARNING IN THE EASTERN COAST OF TANZANIA
}

Daniel SABAI *

* Dar es Salaam University College of Education, Faculty of Humanities and Social Sciences, Department of Geography and Economics, Dar es Salaam, P.O. Box 2329, Tanzania, dsabainew@hotmail.com

KEYWORDS: Praxis, Practice, Natural resource management, Experiential Learning.

\section{ABSTRACT}

It is evident that practice and praxis have significantly contributed to knowledge generation in the Tanzanian coastal belt, especially where Integrated Coastal Management (ICM) programmes have been adopted and practiced such as Tanga, Dar es Salaam, Mtwara, Lindi, and the Coastal region (KICAMP, 2001; NICEMS, 2003). In spite of such learning evidences, users of generated natural resource data in the coastal area tend to employ practice and praxis interchangeably, conflating the two concepts together; leading to a situation where one may hardly ascribe generated knowledge appropriately to contexts that favour occurrence of each of the two constructs. The paper adopts ethnographic approach in a defined coastal case study to examine contexts and situations that signals "conflation" and it employs examples that may help readers of the article to disambiguate praxis from practice.

RESUME: La différence entre expérience et pratique dans la gestion des ressources naturelles: un espace pratique pour l'amélioration de l'apprentissage expérientiel sur la côte est de la Tanzanie.

Il est évident que la pratique et l'expérience ont contribué de manière signifiante à la génération du savoir dans la région côtière de la Tanzanie, particulièrement là où ont été adoptés et mis en pratique lesprogrammes de Gestion Intégrée des Côtes (ICM) tels que Tanga, Dar es Salaam, Mtwara, Lindi et la Région Côtière (KICAMP, 2001; NICEMS, 2003). En dépit des preuves d'apprentissage, les usagers des données générées sur les ressources naturelles dans les régions côtières ont tendance à alterner entre pratique et expérience, confondant les deux concepts et menant à une situation où on peut à peine attribuer le savoir généré de manière appropriée aux contextes favorisant l'occurrence de chacune des deux expressions. L'article adopte l'approche ethnographique dans une étude de cas défini côtier afin d'examiner les contextes et les situations signalant "l'amalgame" et il utilise des exemples afin d'aider les lecteurs de l'article à faire la distinction entre l'expérience et la pratique.

REZUMAT: Diferența între experiență și practică în managementul resurselor naturale: un spațiu practic pentru ameliorarea învățării experiențiale pe coasta de est a Tanzaniei.

Este evident că practica și experiența au contribuit semnificativ la generarea de cunoaștere în centura de coastă a Tanzaniei, în special acolo unde au fost adoptate şi implementate programe de Management Costier Integrat (MCI), ca de exemplu în Tanga, Dar es Salaam, Mtwara, Lindi și Regiunea Costieră (KICAMP, 2001; NICEMS, 2003). În ciuda acestor dovezi de învățare, utilizatorii de date generate despre resursele naturale în zona de coastă tind să utilizeze practica și experiența interșanjabil, confundând cele două concepte, ceea ce conduce la o situație căreia cu greu i se poate atribui generarea de cunoștințe în mod corespunzător contextelor. Articolul adoptă o abordare etnografică într-un studiu de caz costier definit pentru a examina contexte și situații care semnalează „amalgamul” și folosește exemple ce pot ajuta cititorii articolului să facă deosebirea între experiență și practică. 


\section{INTRODUCTION}

This journal article examines the features that distinguish practice from praxis. The argument is illustrated with examples from a natural resource management context in the coastal belt of Tanzania. It addresses two research questions: 1 . What is the theoretical distinction between praxis and practice in the natural resource management context? 2. How can researchers and users of natural resource knowledge avoid collapsing praxis to practice in the experiential learning space?

While both praxis and practice involve actions, the former has some special attributes that differentiate it from the latter. In this paper, praxis is defined as a moral action that follows the logical nature of an intervention and safeguards or benefits the community at large (Kemmis and Smith, 2008). By contrast, practice may or may not be a moral act. Furthermore, if it is a moral act, its morality is not derived from the logic of the intervention, neither does it necessarily benefit the community at large. It may, for example, be a moral act based on fideism (what is good is what an authority figure tells us) or history (what is good is what we have always done in the past). From these definitions, it may be argued that, since praxis carries community interests on board, it always involves more than one individual. However, this may not be the case for practice. In the context of the coast of Tanzania, examples of the practice/praxis divide are common among the different stakeholders involved in the community and institutions involved in Integrated Coastal Management (ICM). The constructs of practice and praxis are often-times mistaken by users of coastal data and information as carrying the same meaning; a situation that attracts confusion and misappropriation of knowledge that is generated from practice and praxis contexts.

This journal article brings examines contexts and situations that signals the "conflation" of praxis and practice and employs examples that may help readers of the article to disambiguate praxis from practice in the coastal resource management context. This can help researchers and users of coastal resources to avoid collapsing praxis to practice in the experiential learning space.

\section{METHODS}

What follows is a brief summary of the materials and methods used in this research. Data generation was pursued through primary and secondary data sources in a case study research context which sought to gain profound insight into on-going coastal-based practices and praxis in a coastal mangrove strip that extends from Moa to Boma localities in Mkinga District (a new district in Tanga Region, North Eastern part of Tanzania).

Case study research can reveal rich insight about the case that is being studied (Yin, 2012) and can help researchers to "retain holistic and meaningful characteristics of real-life events" (Yin, 2003). This study pursued a "descriptive case", which according to Yin (2012) offers "rich and revealing insights into the social world of a particular case".

Primary data generation involved open observation of ongoing coastal practices and praxis and in-depth face-to-face interviews with a total of 10 mangrove restorers, four mangrove-based fishers and eight elders who have lived in the study area for over 10 years. These were selected strategically based on the criteria of their direct involvement in coastalbased practice and praxis. The use of strategic or purposive sample in this case is based on the fact that the study intended to investigate coastal based praxis and practice. As Teddie and $\mathrm{Yu}$ (2007) put it, this kind of sampling is applied "when the individual case itself or a specific group cases is a major focus of the investigation”. 
Secondary data generation involved the use of both existing literature (books, articles and conference proceedings in conceptualising and contextualising praxis and praxis) and analysis and interpretation of existing research data as advised by Verschuren and Doorewaard (1999), especially those that lens occurrence of practice and praxis in the Eastern coast of Tanzania (Fig. 1).

Analysis of primary data involved three sorts of coding in qualitative research, namely, "descriptive, topic, and analytical" as advised by Richards (2005). Descriptive coding focused on describing emerging themes to the level that would allow them to be further analysed. Topic coding, in this case referred to assigning emerging themes under specific topics or subtopics. And analytical coding focused on recontextualising captured data to examine whether the concepts of practice and praxis were a useful initial stage for sub-subsequent levels or layers of analysis.

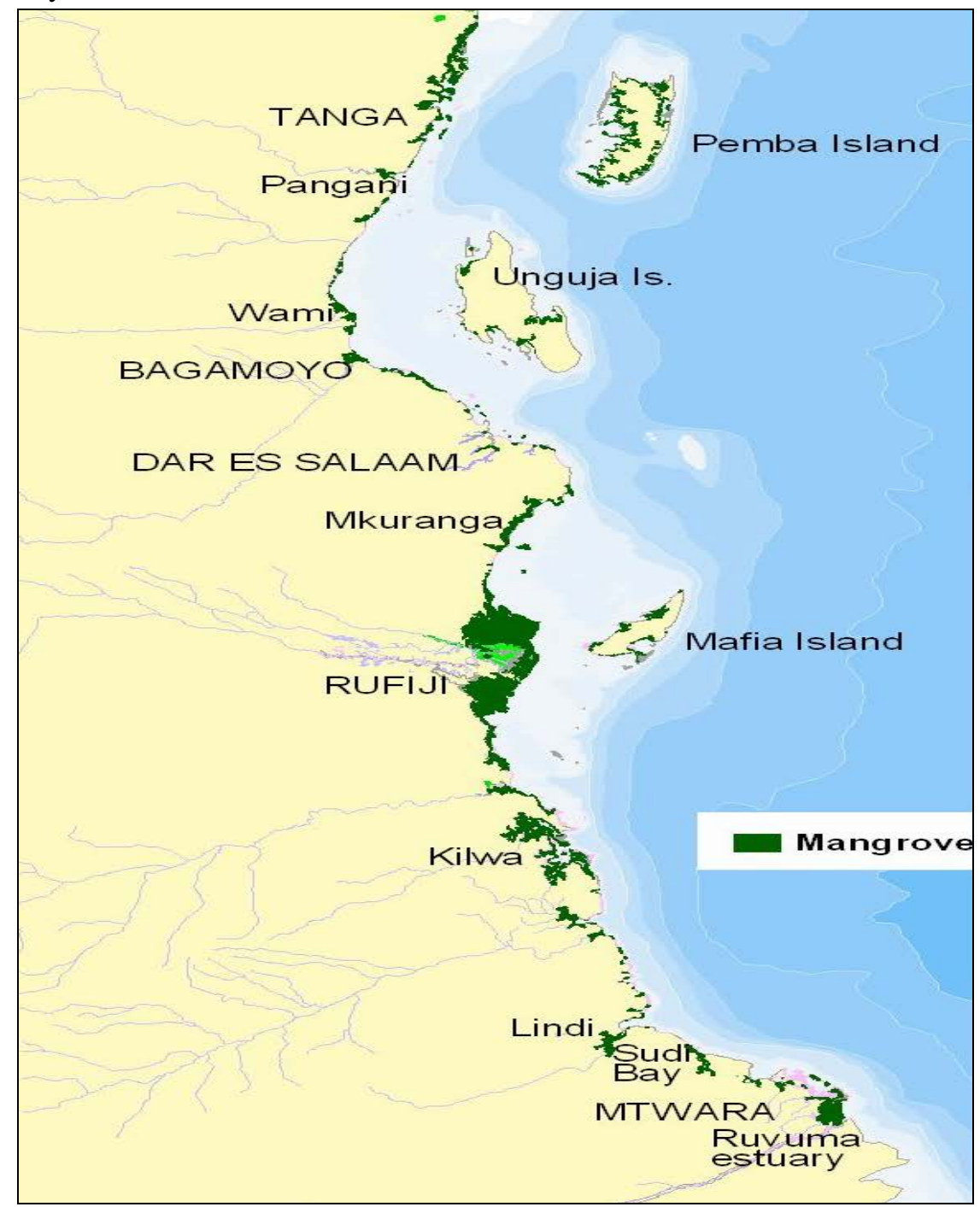

Figure 1: Map of the Eastern Coast of Tanzania indicating regions and districts that are involved in coastal-based practice and praxis (Envirocare, Fea and Tacoecont, 2010). 


\section{RESULTS AND DISSCUSSION}

\section{Summary of secondary data findings}

Integrate Coastal Management (ICM) was adopted in the coastal area of Tanzania in the $1990 \mathrm{~s}$ as a solution to institutional overlaps, coastal resource use conflicts, and mismanagement of resources such as mangroves, fisheries, seagrass, coral reefs, and coastal land (TCMP, 1999a). It leads to praxis-based initiatives that involved various local actors in needs assessment, collective planning, and laying down implementation strategies to achieve agreed initiatives. It prioritized knowledge creation, sharing, and capacity building through processes of training, experiential learning, and engaging in participatory monitoring of coastal resources. It therefore facilitated participatory or collective action by encouraging knowledge sharing towards sustainable use of coastal and marine resources such as mangroves, fisheries, coastal land, seaweed/grass and Cora reefs (TCMP, 1999b).

ICM actions in the 1990s include: Tanga Coastal Zone Conservation and Development Programme (TCZCDP); Rural Integrated Project Support (RIPS); Mafia Island Marine Park (the first Marine Park in Tanzania) established under the Marine Parks; and Reserve ACT.29 of 1994; Rufiji Environment Management Project (REMP); National Mangrove Management Project (NMMP); Saadani Mkwaja Game Reserve; and Kinondoni Integrated Coastal Area Management Programme (KICAMP). All of these initiatives were guided by the principles of ICM (TCMP, 1999a, b); and we can therefore assume that they all employed praxis.

However, while these coastal projects embodied the characteristics of praxis, such as community participation; there was simultaneously a second pattern of activities present that was practice-based. These practice-based activities did not take into consideration the future of the coastal and marine resources. They allowed actors - in processes reminiscent of the tragedy of the commons (Hardin, 1968) - to achieve quick gains guided by experience and routine. They included: the use of coastal mangrove trees to make charcoal; the use of coral reefs to make lime; and the clearing of mangroves to establish salt-pans, make boats or build residential housing (NICEMS, 2003; KICAMP, 2001; KICAMP, 2004). There was therefore a significant distinction between praxis and practice in the natural resource management context (Kemmis and Smith, 2008; NICEMS, 2003; KICAMP, 2001; KICAMP, 2004).

\section{Summary of primary data findings}

The collection of primary data revealed few praxis-orientated activities embarked upon by the locals and facilitated by institutions involved in Integrated Coastal Management. These included: seed harvesting and nursery preparation; seedling transplanting; seed germination; mangrove forests as useful sites for beekeeping; seaweed farming; crab fattening; mariculture.

\section{Seed harvesting and nursery preparation}

Mangrove restorers know the flowering seasons for different mangrove species. When mangrove seeds mature, special nurseries are prepared followed by seed harvesting, selection and transplanting. The number and type of nursery grounds are thus dependent on the need on the ground. Caring for the nursery requires knowledge as it involves the need to understand different needs or requirements for particular mangrove species. Seeds from Avicennia marina (locally called mchu) grow faster and adapt more easily to the nursery environment than other mangrove species such as Bruguiera gymnorrhiza (msinzi or muia), Ceriops tagal (mkandaa), Rhizophora mucronata (mkoko), Sonneratia alba (mpia) and Xylocarpus granatum (mkomafi). Each nursery plot serves a purpose for specific mangrove species depending on identified needs. In other words, a nursery that is aimed for raising Ceriops tagal (mkandaa) is restricted for this particular seedling production and "labelled" to simplify identification. 


\section{Seedling transplanting}

Mangrove seedlings transplanting as a form of praxis is done where were affected by mangrove clearance practices which in most cases appear as bare sites. The demand for seedlings that are required for transplanting in a particular time of the year depends on the size of bare sites observed in the mangrove forest and the type of species that are affected.

\section{Seed germination}

Members of the coastal community, who have never been inducted to the practice before, learn from others as they observe how seeds are picked from mature plants, sorted, soaked for at least 24 hours to quicken germination, and later planted in rows in the nurseries. When the new members are familiar with the practice, they also pass the knowledge they have acquired to others up to a level that attracts more active participation and learning. Avicennia marina (mchu) and Xylocarpus granatum (mkomafi) produce round fruits. The former produces small to medium round fruits which can be collected for nursery purposes while the latter tend to bear much bigger fruits which contain several seeds (Berjack et al., 2011).

Seeds are released when the outer skin of mature fruit tears due to falling or decaying. Mangrove species like Ceriops tagal (mkandaa), Rhizophora mucronata (mkoko), and Sonneratia alba (mpia) tend to produce seeds which germinate while still on the parent plant which enables them to rapidly establish in soft sediments "without being washed away by tide" (Scheltinga et al., 2004). These hang downward, facing the ground, and have sharp endings which stick and germinate in the mudd after falling. These seeds can also be harvested and planted in nursery grounds or directly pinned to the ground by mangrove restorers.

\section{Mangrove forests as useful sites for beekeeping}

In the coastal area, beekeeping is carried out as practice and praxis at the same time. Some members of the coastal community started engaging in beekeeping after attending organized training sessions under the support of ICM programmes in their areas. These later pursued specified logical plans to implement beekeeping in the mangroves. On the contrary, some individuals practice beekeeping in the absence of logical plans or without carrying on board community aspirations and expectations. The latter as alluded earlier in the introductory part is a form of practice rather than praxis (Kemmis and Smith, 2008).

Be keeping as an emerging viable economic praxis has many benefits, not only to coastal communities as an income generating activity, but also to the mangrove ecosystem. Mangrove restorers select certain mature mangrove plants which can support the installation of modern beehives. Areas that are covered by beehives remain undisturbed throughout the year in fear of the African honey bees which are aggressive by nature (Hodgson et al., 2010) and can attack people who disturb the surrounding environment or who cut trees near the beehives. Honey and bee products from the mangrove area are considered to have medicinal benefits, and are thus widely preferred by coastal dwellers to honey from terrestrial forests.

\section{Seaweed farming}

Seaweed farming is a common practice in the study area. There are two species that are farmed in the Eastern Coast of Tanzania. These are Eucheuma spinosum and Eucheuma cotonii. Seaweed farming is practiced at a medium scale where selected species are tied in specified strings and placed in deep or shallow water to grow. Harvesting time range from few weeks to three months, depending on location of the farm and absence of predators such as rabbit fish (Siganus spp.) and other fish (Talbot and Wilkinson, 2001). Rafts such as plastic bottles or other light materials are also tied to the string (s) to help seaweed farmers identify farm demarcations, as these float and may easily be seen or detected from a distance. 
Several studies have associated seaweed farming with increased catches of particular fish species. These studies reveal that fishing traps (gear) set near seaweed farms caught three times more fish than those placed elsewhere (Eklöf et al., 2006).

\section{Crab fattening}

Crab fattening is simply an act of catching or fishing mud crabs (Scylla serrata) and keeping them in locally made cages in the mangrove areas and feeding them until their weight increases relatively. Mud crabs are caught at juvenile stage and are fed with fish off al organs of animals such as livers, hearts, intestines, etc., internal, oyster meat, and gastropods (Melita et al., 2008) to encourage quick growth to market size. This process seems to be viable economically since crab weight determines the price. The more the weight the higher the income. Locally made cages require traditional skills and knowledge, and this can be carried out by people who understand the biological and natural behaviour of the crabs. In spite of the fact that crab fattening is a morally accepted action, it is still narrowly practiced in the coastal area and may hardly qualify to be regarded as a form of praxis as there are very few individuals who are engaged in it and they do it through locally acquired experiences.

\section{Mariculture}

The Tanzanian Coast also has the potential for oyster farming as a type of mariculture but this does not involve local creativity as it is the case in other parts of the coastal area. Unlike crabs, oysters are directly harvested from their natural environment and consumed. Mangrove oysters (Saccostrea cucullat) are common and abundant on the eastern coast of Tanzania as a potential culture species (Rice et al., 2006). Oyster farming allows involved actors to raise oysters either for commercial purposes or home consumption (Rice et al., 2006). It is believed that this form of practice is not widely carried out, due to a limited market and the abundance of wild oysters (TCZCDP-2008).

\section{Discussion of praxis-oriented activities}

The described activities exhibit the characteristics of praxis because they induce benefits to the environment and the local human communities. Preparation of nursery grounds and transplanting seedling contribute to the maintenance of the mangroves and therefore protect the socioeconomic environment. They encourage not only learning by doing among mangrove restorers, but also knowledge transfer from individual levels to a wider level of the social unit (i.e. social learning). Some of the activities allow individuals to use resources, or add value to them, in non-exploitative ways. For instance, seaweed-farming, crab-fattening and mariculture, carried out appropriately, need not be harmful to the environment but significantly increase resource yields. Such activities may have also have beneficial effects on the local ecology, for instance, bees contribute to species pollination and seaweed creates habitats for fish species. Praxis, according to this definition, requires that actors do not take advice on the basis of external authority alone; rather actors are guided by the logic of the context, and decisions are made collectively. This makes praxis profoundly democratic.

Prior to the introduction of beekeeping and other economic practices like crab fattening in the mangroves, the secondary data revealed that there were debates over whether it was justified to include poor communities in projects such as mangrove restoration, since it was believed that these had no direct and tangible benefits to the people (KICAMP, 2003). Such debates no longer exist - as the benefits are now clear - and more people, especially women, are attracted to such projects in the mangrove sites. Additionally, it was arguably paternalistic of the people who engaged in such debates, in that they assumed that local people would not value the long-term advantages of protecting the mangroves. 
An explanation for how the poor communities came to engage in praxis is specifically provided by the idea of Community of Practice (CP) developed by Etienne Wenger (1998) to serve as a lens for indicating a process pursued by people with a shared concern or passion - in a defined domain - as they learn how to do better through regular interactions. As these people work together, they develop a form of specific common identity, leading to shared commitment and also competencies. Similarly, the events and praxis described in this particular article can be understood in terms of the theoretical concept known as "experiential learning” which draws heavily on Kolb's theory of Experiential Learning (Kolb, 1984). It explains how people learn as they engage in practice, the role of experience in the learning process, and the learning styles that emerge as actors immerse in the learning practice or praxis.

\section{How to achieve praxis rather than practice}

Praxis is a particular kind of "action" (Kemmis and Smith, 2008). In order to understand it fully, there is a need to abstract it further by isolating out some of its key component parts, particularly those that differentiate it from a mere action or social practice. As alluded in the preamble, it is a kind of action that takes into account not only individual interests but also long term interests of the society or a particular community (ibid.), and a morally-committed and oriented action that is informed by traditions in the field and expectations of bringing about some kind of transformation in the social world. Praxis tends to accommodate reflections and reflexivity of involved communities. It avails a space for target communities to pursue logically planned actions and improve, correct, or replace them as they engage in continued the implementation process. Any actions that encourage reflexivity are capable of providing a space for involved communities to critique their own work and generate a higher degree of freedom to for them to point out constraints and needs that are necessary for achieving the intended results (Bourdieu, 2004). Through such a process, there is always some kind of learning which is being attained (Wals, 2007). This kind of learning, that allows people to learn as they engage in practice, is also known as Experiential Learning (Kolb, 1984; NEECS, 2004).

Developing praxis requires opportunities for experiential learning and an environment that favours field work and traditions of practice (Kemmis and Smith, 2008). It requires that learners identify themselves as people who try to develop their knowledge and practices within their social context through action, experience, and reflection (ibid.).

Knowledge was gained through both personal and environmental experiences (Kolb, 1984). Kolb argues further that for knowledge to be gained, four conditions must be fulfilled; firstly, the learner must be willing to be actively involved in an experience; secondly, he or she must be able to reflect on the experience; thirdly, she or he must be able to conceptualize that particular experience; and finally, he or she should possess decision making and problem solving skills in order to apply ideas gained from experience (ibid.). The second and third conditions that Kolb brings into consideration can hardly be reached without the process of abstraction and careful conceptualisation. The last condition in the process of "experiential learning" which requires the learner's ability and skills to internalize gained knowledge or experience can be referred as "Praxis". It is at this point that praxis potentially affects experiential learning. 


\section{Monitoring as a form of praxis which attracts learning}

Monitoring is defined as a process that involves repeated surveys in which "qualitative or quantitative" observations are made (Hill et al., 2005). It involves detecting of changes, trends, threats, and the condition of specified parameters of the environment (KIMP, 2005), and is carried out for different purposes depending on what it is aimed at (Hill et al., 2005). Monitoring is a good ground for experiential learning, and as discussed earlier in this article, it potentially allows actors (local communities) to learn from each other to the level that may enhance their praxis and attract a wider participation of learners.

Hill et al. (2005) insist that a monitoring programme needs to have a defined or formulated standard; which should specify the kinds of features that will be monitored, for example mangroves, and fisheries; it should also specify attributes for selected features' (e.g. soil, vegetation cover, etc.) target state, and the methods that will be employed in the process of monitoring. Monitoring, according to Hill et al. (2005), should therefore: establish whether standards are being met; detect change and trigger responses if any of the changes are undesirable; contribute to the diagnosis of the causes of change; and assess the success of actions taken to maintain standards or to reverse undesirable changes, and where necessary, contribute to their improvement.

Formulating "standards" implies choosing a preferred monitoring-route that is based on actors' priorities or preferences. The "standard" therefore, serves as a guideline of inclusion and exclusion of monitoring parameters all of which depict a praxis path.

Monitoring as a form of praxis in the coastal area requires an agreed set of parameters, attributes, and methods or techniques (KIMP, 2005). General monitored parameters include trends, condition, threats and changes (ibid.). Monitored attributes vary across prioritized natural resources; and their selection will normally depend on the purpose of monitoring and the resource condition (Hill et al., 2005).

\section{CONCLUSIONS}

Praxis has a positive connotation. Its epistemology facilitates the adoption of moral actions based on the logical nature of an intervention and protects or benefits the wider community. Praxis is associated with reflexivity, in that, it allows involved actors to reflexively consider their actions and improve or discard unwanted ones. It results in creative approaches to novel situations and its base in democratic, collective decision making makes it ethically sound, since it avoids top-down management. There are cases where adopted logical plans fail to capture local needs and concerns; but these are always potentially resolvable since praxis-oriented initiatives encourage learning from mistakes. There are many well-established approaches and tools that can assist in the achievement of praxis, such as: Wenger's (1998) theory of Communities of Practice; Kolb’s (1984) theory of Experiential Learning; and general features of monitoring and evaluation, see for example Hill et al. (2005).

Practice, as defined in this article, is usually problematic. Even if its immediate form is harmless or beneficial, there is always the potential for practice to result in disadvantageous actions, especially over-time. This is because it cannot account for changes in circumstances and its lack of reflexivity denies the possibility of monitoring and behaviour adjustments. Because it does not necessarily consider the wider community or long term consequences, it is susceptible to the problem of the tragedy of the commons. Not only does practice encourage detrimental activities; it can also inhibit the expansion of activities that are beneficial, as is the case with crab-fattening. By differentiating between practice and praxis, is hoped that resource managers will be better equipped to develop greater praxis in resource management contexts. 


\section{ACKNOWLEDGEMENT}

Acknowledgement goes to coastal communities who took part in this research and Mrs. Lotz-Sisitka H., and Mr. O’Donoghue R. for advising me on various issues that relate to learning in the coastal context. I would also like to thank Mrs. Leigh Price for useful comments on an early draft. 


\section{REFERENCES}

1. Berjack P., Campbell G., Huckett B. and Pammenter N., 2011 - In the Mangroves of South Africa, KZN: WESSA.

2. Bourdieu P., 2004 - Science of Science and Reflexivity, Cambridge, Polity Press.

3. Eklöf J. S., Torre-Castro M., Nilsson C. and Rönnbäck P., 2006 - How do seaweed farms influence local fishery catches in a seagrass-dominated setting in Chwaka Bay, Zanzibar? Aquatic Living Resources, 19, 137-147.

4. Hardin G., 1968 - The Tragedy of the Commons, Science, 162, 3859, 1243-1248.

5. Hill D., Fasham M., Tucker G., Shewry M. and Shaw P. (eds), 2005 - Handbook of biodiversity methods: Survey, evaluation and monitoring, New York: Cambridge University Press.

6. Hodgson E. W., Stanley C. A., Roe A. H. and Downey D., 2010 - African Honey Bees, Logan, Utah State University.

7. Julius A., 2005 - Monitoring Programme for resource condition, environmental and biological parameters for Mnazi-Bay Ruvuma Estuary Marine Park (MBREMP) Tanzania, Research Report submitted for the requirement of United Nations University Fisheries Training Programme.

8. Kemmis S. and Smith T. J. (eds), 2008 - Enabling Praxis, Challenges for education, Rotterdam: SensePublishers.

9. Kinondoni Integrated Coastal Area Management Programme, 2001 - Inception Report, Dar es Salaam: SSPA.

10. Kinondoni Integrated Coastal Area Management Programme, 2003 - Annual Progress Report, Dar es Salaam: SSPA.

11. Kinondoni Integrated Coastal Area Management Programme, 2004 - Phase One, Final Report, Dar es Salaam.

12. Kinondoni Integrated Monitoring Plan (KICAMP), 2005 - Dar es Salaam: Dynamite in KICAMP area, University of Dar es Salaam.

13. Kinondoni Integrated Monitoring Plan (KIMP), 2005 - Dar es Salaam: FAST, University of Dar es Salaam.

14. Kolb D. A., 1984 - Experiential learning: Experience as the source of learning and development, New Jersey: Prentice Hall.

15. Melita A., Samoilys M. A. and Kanyange N. W., 2008 - Natural resource dependence, livelihoods and development: Perceptions from Tanga, Tanzania, IUCN ESARO 2008.

16. National Integrated Coastal Environmental Management Strategy (NICEMS), 2003 - Dar es Salaam: Tanzania Coastal Management Partnership.

17. National Environmental Education and Communication Strategy, 2005-2009 - Dar es Salaam: Rihal's General Supplies.

18. Report on the Implementation of the Mangrove Restoration Project in Mkinga District, 2010 Envirocare, FEA, and TACOECONT, Dar es Salaam.

19. Richards L., 2005 - Handling Qualitative Data. A practical guide, London: Sage.

20. Rice M. A., Mmochi A. J., Zubieri L. and Savoie R. M., 2006 - Aquaculture in Tanzania, World Aquaculture, 37, 50-57.

21. Rice M. and Pinnegar S., 2012 - Reflection under construction: Using the handbook of reflection and reflective inquiry in practice, Reflective Practice, International and Multidisciplinary Perspectives, 13, 821-827.

22. Scheltinga D. M., Counihan R., Moss A., Cox M. and Bennet J., 2004 - User's Guide to Estuarine, Coastal and Marine Indicators for Regional Natural Resource Management, Cooperative Research Centre for Coastal Zone, Estuary and Waterway Management, Science Daily, October 2005, Retrieved on 15th January 2013 from www.sciencedaily.com/releases/2005 
23. Talbot F. and Wilkinson C., 2001 - Coral reefs, mangroves and sea-grasses: A source book for managers, Australian Institute of Marine Science.

24. Tanga Coastal Zone Conservation and Development Programme (TCZCDP): Annual Progress Report, 1st April 2004 - 31st March 2005.

25. Tanzania Coastal Management Partnership - TCMP, 1998 - Proceedings of the scientific meeting on marine and coastal ecosystem risk assessment, An approach for linking Science to Integrated Coastal Management, Zanzibar: TCMP and IMS.

26. Tanzania Coastal Management Partnership (TCMP), 1999a - Initial Elements of a Coastal Policy, Proposed Vision, Principles, Goals and Strategies, Working document no. 5018, Dar es Salaam: TCMP Support Unit.

27. Tanzania Coastal Management Partnership (TCMP), 1999b - Options for a National Integrated Coastal management Policy, Working document no. 5026, Dar es Salaam: TCMP Support Unit.

28. Teddie C. and Yu F., 2007 - Mixed Methods Sampling. A Typology with Examples, Journal of Mixed Methods Research, 1, 77.

29. The Western Indian Ocean Marine Science Association (WIOMSA), Monitoring mangroves and sea grasses in Marine Protected Areas, A Toolkit for Western Indian Ocean:www.wiomsa.org/mpatoolkit/Themessheers/G4_MonitoringAccessed in January, 2011.

30. Vershuren P. and Doorewaard H., 2010 - Designing a Research Project (2nd Ed.), Den Haag: Eleven International Publishing.

31. Wagner G. M., Mgaya Y. D., Akwilapo F. D., Ngowo R. G., Sekadende B. C., Allen A., Zollet E. A. and Mackentley N., 2001 - Restoration of coral reef and mangrove ecosystems at Kunduchi and Mbweni, Dar es Salaam with community participation, in Richmond M. D. and Francis J. (eds), Marine Science Development in Tanzania and Eastern Africa, Dar es Salaam: University of Dar es Salaam, 467-488.

32. Wagner G. M., 2005 - Participatory monitoring of changes in coastal and marine biodiversity, Indian Journal of Marine Sciences, 34, 1, 136-146.

33. Wals A. E. J. (ed.), 2007 - Social learning towards a sustainable world, Wageningen: Wageningen Academic Publishers.

34. Wenger E., 1998 - Communities of Practice: Learning, meaning, and identity, Cambridge: Cambridge University Press.

35. Yin R. K., 2012 - Case Study Research Design and Methods, London, Sage. 